\title{
A corrupção na Época Moderna - conceitose desafios metodológicos
}

\author{
Adriana Romeiro[1]
}

\begin{abstract}
Resumo
Este artigo aborda o conceito da corrupção nas sociedades da Época Moderna,indagando sobre a sua pertinência naquele contexto histórico. A partir de uma investigação sobre os significados da palavra corrupção nos textos coevos,propõe-se a refletir sobre as noções que estruturavam o imaginário do mau governo. Considerada um vício,a ambição desmedida dos governantes era objeto de condenação nos textos políticos e morais da época,sendo apontada como uma das causas da corrupção do corpo da República.
\end{abstract}

Palavras-chave: Corrupção; Época Moderna; História.

\section{The corruption in the Modern Age - concepts and methodological challenges}

\begin{abstract}
This article discusses the concept of corruption in the societies of the Modern Age, inquiring about their relevance in that historical context. From an investigation into the meanings of the word corruption in coeval texts, it is proposed to reflect on the notions that structured the imaginary about the bad government. Considered a vice, the excessive ambition of rulers was condemnation object in political and moral texts of the time, being considered one of the causes of corruption of the body of the Republic.
\end{abstract}

Keywords: Corruption; Modern Age; History.

\section{La corrupción en la Edad Moderna - conceptos y desafíos metodológicos}

\section{Resumen}

Este artículo aborda el concepto de corrupción en las sociedades de la Edad Moderna, preguntando acerca de su relevancia en este contexto histórico. A partir de una investigación sobre los significados de la palabra corrupción en los textos coetáneos, se propone reflexionar sobre las nociones que estructuraron el imaginario del mal gobierno. Considerada un vicio, la ambición desmedida de los gobernantes era objeto la condena en los textos políticos y morales de la época, siendo considerado una de las causas de la corrupción del cuerpo de la República.

Palabras clave: Corrupción; Edad Moderna; Historia.

\section{La corruption dans l'époque moderne - concepts et défis méthodologiques}

\section{Résumé}

Cet article traite de la notion de la corruption dans les sociétés de l’ère moderne, renseigner sur leur pertinence dans le contexte historique. De une enquête sur les significations du mot corruption dans les textes contemporaines, il est proposé de réfléchir sur les notions qui structurent le mauvais gouvernement de l'imaginaire. Considéré comme un vice, l'ambition excessive des dirigeants était l'objet de la condamnation dans les textes politiques et morales de l'époque, est considérée comme l'une des causes de la corruption du corps de la République.

Mots-clé:Corruption; Age moderne; Histoire. 
$\mathrm{O}$ bjeto de intenso debate, a aplicação do conceito de corrupção às sociedades da Época Moderna impõe problemas teóricos e metodológicos complexos, obrigando o estudioso a um esforço de conceptualização, para elidir os riscos de anacronismo. Riscos como, por exemplo, o de se aplicar noções próprias da burocracia do Estado liberal em contextos caracterizados pela indistinção entre as esferas pública e privada, nos quais práticas hoje condenadas gozavam de legitimidade, sendo socialmente aceitas. Ou ainda, havia a tendência a se confundir os padrões de recrutamento e atuação dos agentes de uma administração baseada na lógica de serviço régio, com os padrões de racionalização do funcionalismo moderno (Arancivia, 2007; Bertrand, 1999).

O primeiro passo, então, consiste em buscar as acepções da palavra em seu próprio tempo, indagando sobre a realidade que ela recobria. Derivada do latim "corruptione", que significa putrefação, decomposição e adulteração,a palavra conservou nas línguas vernáculas a acepção original latina, como mostra, por exemplo, Bluteau em seu Vocabulario Portuguez \& latino, que a define como "suspensão do concurso conservativo, e introdução de qualidades alterantes, e destrutivas." A esse caráter físico, ele acrescenta outro metafórico, aludindo à corrupção dos costumes, à corrupção do juiz ou da justiça; e à corrupção de palavras (Bluteau, 1728, p. 572). Décadas depois, Antônio de Moraes Silva, em seu Dicionário da Língua Portuguesa, de 1789, sintetizaria tais acepções - "o estado da coisa corrupta ou corrompida" ou "alteração do que é reto ou bom, em mau e depravado" - associando-a, porém, ao ato de "perverter, subornar, peitar" (Silva, 1813, p. 479). Na verdade, o emprego da palavra em um sentido metafórico, aplicada ao campo da moral, da justiça e dos costumes, encontra-se disseminado nos tratados políticos e morais da Época moderna, remontando a um período muito anterior, como se pode observar nas Ordenações Afonsinas: uma lei de 1314, por exemplo, estabelecia as penas aos que tentavam influenciar o julgamento das causas, recorrendo às peitas, "para corromper e impedir o andamento legal do pleito" (Ordenações Afonsinas, 1314).

Até o final do século XVIII, o emprego da palavra em sua acepção física ou biológica conviveu lado a lado com a sua acepção política, como se observa na obra Agricultor instruído, de 1730, destinada a oferecer conselhos práticos sobre, entre outras coisas, as sementeiras, discorrendo sobre "as virtudes das sementes, e de como se preservarão da corrupção" (Maria, 1730, p. 1). Ou, ainda, no Thesouro apollineo, galenico, chimico, chirurgico, farmacêutico, de 1714, em que se descrevia a corrupção dos ossos: "corrompe-se ou faz-se carioso qualquer osso, ou por diuturno fluxo de humores, ou por sua acrimonia" (Vigier, 1714, p. 418). Muito disseminado foi também o emprego da palavra em sua conotação moral, para se referir, por exemplo, aos costumes, como se pode notar em uma passagem sobre o luxo, a respeito do qual o autor escreve que se devia apartar "da sociedade tudo o que pode corromper os costumes" (Silva, 1789, p. 210).

Na língua castelhana, a palavra guarda idênticas acepções, como se constata no Tesoro de la lengua castellana o española, de 1611, onde Covarrubias afirma ser originária da raiz latina "corrumpo, contamino, vitio, destruo", apresentando 
dez acepções, relacionadas à degradação biológica - "pudrimiento" - e à moral, como o suborno, os costumes, a defloração de mulher virgem, a falsificação de documentos, além da corrupção das palavras." (Orozco, 1995, p. 359). No Thresor de la langue françoyse tant ancienne que moderne, publicado em 1606, Jean Nicot, à semelhança de Covarrubias, distingue tanto um sentido biológico - "corruption totale d'aucun membre" - , quanto um sentido moral - "juger sans corruption." (Nicot, 1606). Quase um século depois, Antoine Furetière, em seu Dictionnaire de l'Académie française (Furetière, 1694) de 1694, manteria intactas as definições de Nicot, acrescentando, porém, que a corrupção biológica também designava o processo de geração e produção de um novo corpo. A corrupção moral abrangia o campo dos costumes, da justiça, da fidelidade e da pudicícia.

Pode-se concluir que poucas foram as flutuações semânticas da palavra ao longo dos séculos XVII e XVIII, prestando-se ela a designar os comportamentos morais ilícitos. Se a noção de corrupção, no sentido de desvio moral ou político, não era estranha ao imaginário político da Época Moderna, é de se notar, porém, uma diferença significativa entre os usos contemporâneos da palavra e os do passado. Ao contrário do que ocorre em nossos dias,a corrupção não designa as práticas, mas é, antes, o resultado de práticas que geram a putrefação do corpo da República;ou seja,as práticas não são em si corruptas: elas desencadeiam o processo de corrupção. Ou ainda,o indivíduo que pratica atos ilícitos não é propriamente corrupto,mas sim corruptor. É a partir do final do século XVIII que a palavra sofre um crescente deslizamento semântico, tornando-se, aos poucos, sinônimo de práticas corruptoras, como deixa ver o dicionário de Antônio de Moraes Silva.

\section{Ao contrário do que ocorre em nossos dias, a corrupção não designa as práticas, mas é, antes, o resultado de práticas que geram a putrefação do corpo da República}

Mais comuns do que a palavra corrupção, as práticas que a desencadeiam foram registradas, com surpreendente prodigalidade, tanto nas fontes documentais de caráter administrativo, quanto nos escritos político-morais da época. E muitas das ações tidas hoje por corruptas, aparecem referidas nos textos da época, a exemplo da palavra "peita", que Bluteau define como "qualquer cousa que se dá para subornar o juiz e corromper a justiça” (Bluteau, 1728, p. 369).

Sobre tais práticas, tidas por espúrias e delituosas, condenadas socialmente a ponto de suscitar a indignação moral, recaía uma legislação rigorosa: conforme diz Bluteau, "segundo as Ordenações do Reino, peita prometida, aceitada, e não recebida, basta para fazer perder o oficio, e demais paga-se o tresdobro para a Coroa" (Bluteau, 1728, p. 369). Aqueles que incorriam nesse crime,estavam sujeitos ao degredo e até mesmo à pena de morte (Ordenações Afonsinas,livro III, título 128). 
Ações que resultavam em corrupção política eram designadas por delitos, práticas delituosas ou ilícitas. Assim, não é tanto a corrupção quanto as práticas que a engendram o que está em jogo nos textos políticos e jurídicos do Antigo Regime. E, de fato, como aponta Michel Bertrand, aquelas expressões são relativamente abundantes na época (Bertrand, 1999, p. 21); em vez de corromper, preferia-se o verbo delinquir, a exemplo de um parecer do Conselho Ultramarino, datado de 1703, em que, desvanecidas as suspeitas de envolvimento do governador Francisco Naper de Lencastre, no contrabando de madeira e breu na região platina, os conselheiros observaram que ele "de nenhuma maneira delinquiu", acrescentando ainda que tais denúncias eram "gravíssimas". ${ }^{2}$ As palavras "delinquir", que Bluteau explica como "cometer um delito, uma falta, um pecado" (Bluteau, 1728, p. 50), e "delinquente" eram mais comuns para designar o ato de corromper e o indivíduo que corrompe, respectivamente.

É a partir do século XVI que começa a aparecer na Península Ibérica uma série de tratados sobre a moralidade dos agentes da administração, exaltando a imparcialidade e a honestidade como virtudes essenciais ao bom exercício de suas atividades. Como aponta Pietschmann, nesses textos, é possível detectar um esforço de disciplinarização, que se traduz na tentativa de fixar um quadro de referências ético-morais,capaz de abarcar todas as esferas de atuação,desde o exercício das funções propriamente dito até as relações com a sociedade à volta (Pietschmann, 1998, p. 35). Essa literatura moralizante insere-se nos escritos sobre a arte de governar, que, segundo Foucault, difere dos conselhos ao príncipe da Antiguidade e da Idade Média, à medida que apresenta um novo olhar sobre o problema do governo. Certamente, o tema do comportamento do aparato burocrático e o esforço normativo-legal que resulta dele,articulam-se ao "problema do governo de si mesmo", formulado a partir da filosofia neoestóica, coincidindo, portanto, com a publicação das obras de Sêneca em fins do século XV e os debates que se seguiram em torno da questão da virtude (Foucault, 1982, p. 277).

Um exemplo é a obra Política para corregidores y señores de vasallos, publicada em 1597, em cujas páginas Castillo de Bovadilla examina questões espinhosas dos procedimentos dos corregedores e juízes, como a parcialidade, o suborno e a fraude, sustentando que nas "causas capitais e graves", a exemplo da venalidade, os infratores deveriam perder o cargo e incorrer em penas pecuniárias. Bovadilla atribuía à imparcialidade do corregedor a sua razão de ser, dado que, em um mundo em que "todas as coisas militam em contenda umas com as outras", competia a ele ser "fiel e medianeiro entre os súditos, de maneira que que não seja notado de favorável nem parcial” (Bovadilla, 1775, livro II, cap. IX, p. 235).

Outra obra relevante é a República y polícia christiana, publicada em 1615, onde frei Juan de Santa María discorre sobre os abusos praticados pelos que servem ao rei, observando que "os oficiais entram com pouco e saem com muito",

${ }^{2}$ Arquivo Histórico Ultramarino (AHU), Rio de Janeiro, CA, doc. 2630. Lisboa, 6 mar. 1703. 
o que deveria ser remediado com a criação de um decreto, inspirado em uma lei do imperador Antoniano Pio, obrigando os oficiais do Estado a declarar, quando entrassem e saíssem dos seus cargos,o montante de seu patrimônio - como casas, terras, rendas e morgados. Tal medida viria a ser implementada, pouco depois, por Felipe IV, em 1622 (Santa María, 1619, p. 52). Frei Juan de Santa María dedica ainda todo um capítulo às "qualidades dos ministros e conselheiros", notando que a cobiça - que compara a uma peste incurável e contagiosa - é um dos piores vícios, pois que perverte a justiça, deplorando os que se deixam contaminar por ela - "extremada e lamentável miséria, que seja sua avareza e cobiça tanta, que venda a sua alma pelo interesse do dinheiro" (Santa María, 1619, p. 47).

Escritos como o de Castillo de Bovadilla e Juan de Santa María ancoravam-se tanto na tradição clássica, quanto na tradição cristã, para condenar os abusos e excessos dos maus funcionários, e ambas proporcionaram não só um sólido quadro de referências e conceitos morais,mas também um variado repertório de exemplos históricos. Segundo Bovadilla, o próprio Jesus Cristo havia discorrido sobre as virtudes necessárias ao bom ministro (Bovadilla, livro 1, cap. III, p. 41);dos pensadores da Antiguidade,ele cita sobretudo Cícero - particularmente os textos sobre a corrupção em Roma (Dickinson, 1963) - como o guia para a atuação dos magistrados, reproduzindo uma de suas idéias centrais:"coisa de louco é (disse Cícero) que encarreguem de corrigir os delitos o que de emendar os seus está esquecido" (Bovadilla, livro I, cap. III,p. 41).

Para ambos, ações como suborno e venalidade constituem vícios, praticados por homens dominados por paixões violentas, e situam-se entre os pecados que, por ofender a Deus, exigem condenação e castigo. Trata-se, portanto, de um problema moral do indivíduo - e não da sociedade como um todo -, que tem efeitos deletérios sobre o Estado, da mesma forma que a depravação dos costumes (Waquet, 1984, p. 115).

Esse movimento de disciplinarização dos agentes da administração,no sentido de se estabelecer um conjunto de normas e regras legais para o exercício de suas funções, encetado principalmente por letrados e juristas,coincide com difusão das obras de Sêneca no final do século XV e o alastramento da influência do neoestoicismo (Leiva, 2007, p. 50). Herdeira do estoicismo tardio de Sêneca e de Tácito,essa doutrina constitui uma das principais referências para a o modelo político dos estados modernos,baseado em um poder estável,em uma burocracia eficaz e em um exército disciplinado (Oestreich, 1982, p. VII). Para tanto,postula uma técnica especializada e rigorosa em matéria de governo e administração,que resulta em um novo modelo de homo politicus,assentado na educação moral e política dos burocratas e funcionários (Gutiérrez, 2006, p. 724).

Para Peer Schmidt, a recepção das obras de Tácito e Sêneca,por via de Justo Lipsio,a partir de fins do século XVI,e o elogio de valores como constantia,patientia e firmitas,tiveram um forte impacto não só nas obras políticas sobre a América, mas também na práxis da administração colonial (Schmidt, 1997, p. 181). Estudos posteriores, desenvolvidos por Salvador Cardenas Gutiérrez,apontaram 
o papel decisivo das ideias neoestóicas no combate às mais diferentes formas de corrupção por parte dos pensadores da Nova Espanha,responsáveis pela produção de uma literatura áulica,empenhada em refletir sobre a dimensão moral do governo dos povos (Gutiérrez, 2006, p. 717).

Dessas considerações, pode-se concluir que o vocabulário do Antigo Regime registrava uma rica gama de comportamentos ilícitos, identificados por palavras como abusos, violências, excessos e ilicitudes, que recobriam, por sua vez,práticas como contrabando,venda de cargos e sentenças,favorecimento de particulares,entre outras. Tais práticas ultrapassavam a dimensão meramente econômica para abarcar também aspectos mais estritamente políticos, como eram o abuso de autoridade, a falta de lealdade ao rei ou o atropelo das jurisdições (Norris, 2000, p. 685). É,portanto, legítimo o uso do conceito de corrupção para a sociedade da Época Moderna, não como sinônimo de práticas tidas então por delituosas,mas como sinônimo dos seus efeitos desagregadores sobre a República e, é claro, desde que se leve em consideração a sua íntima relação com uma visão orgânica da sociedade, concebida como análoga ao corpo humano. É, aliás, curioso observar que o conceito de corrupção aplica-se melhor àquela sociedade do que ao mundo contemporâneo e o uso corrente da palavra em nossos dias é uma apropriação anacrônica de um conceito que pouco se ajusta a uma sociedade que já não se concebe mais como corpo e, portanto, já não é mais passível de degradação física.

Bluteau se refere à limpeza de mãos como a "virtude do juiz, que não toma peitas, que não se deixa corromper com dinheiro", citando um trecho de Fedro, de Platão (Bluteau, 1728, v. II, p. 572). Bovadilla também faz o elogio da lisura e honestidade,às quais dedicou todo um capítulo,observando que os tebanos representavam os juízes sem mão,porque eles não haviam de receber dons. Para ele,a cobiça é uma paixão que suspende o juízo,comprometendo a retidão da justiça. Da limpeza das mãos,necessária ao bom desempenho das funções dos juízes e corregedores,depende,em suas palavras,"a boa governação das Repúblicas" (Bovadilla, 1775, t. 1, p. 21).

A limpeza de mãos constituía um valor moral na sociedade do Antigo Regime. Tratava-se de virtude necessária não só aos governantes,mas a todo aquele que tivesse sob a sua responsabilidade a administração dos bens financeiros de outrem. A partir do princípio do século XVII, por iniciativa do governo filipino,assiste-se, em Portugal, a um esforço normativo-legal que se reflete na multiplicação dos alvarás e cartas que visam estabelecer limites entre o enriquecimento lícito e o ilícito. Questões como a participação em atividades econômicas e a acumulação de fortuna, durante o exercício de cargos administrativos, suscitaram um intenso debate e estiveram na origem da reforma administrativa elaborada pelo Conde Duque de Olivares,permeada por um inegável cunho moralizador. Segundo o valido de Felipe IV,a Espanha e seus domínios encontravam-se em uma situação catastrófica,nascida do fato de que a ambição imperava desenfreada,como nunca se tinha visto antes (Alonso, 1990, p. 283). Para coibir esse estado de coisas, Olivares implementou um conjunto de medidas com o propósito de extinguir as práticas venais de 
toda natureza e o enriquecimento ilícito durante o exercício de cargos administrativos, o que culminou com aquele decreto de 1622, que obrigava a todos os ministros e oficiais dos Reinos a fazer um inventário de suas fazendas, antes e depois de receberem qualquer cargo ou ofício "de qualquer qualidade que seja" (Alonso, 1990, p. 292).

Na Espanha, vigoravam, desde o ano de 1500, os juízos de residência,criados pelos Reis Católicos para funcionar como um mecanismo de fiscalização dos funcionários e ministros régios,por meio de uma rigorosa devassa de seus procedimentos. Nos autos de residência, como eram denominados em Portugal,além dos aspectos relativos à comportamento moral e religioso,constava invariavelmente um item específico sobre a limpeza de mãos dos sindicados: na residência tirada ao governador do Rio de Janeiro,Luiz César de Meneses, por exemplo, concluiu-se que ele fora "limpíssimo de mãos" . ${ }^{3}$

\section{Bluteau se refere à limpeza de mãos como a "virtude do juiz, que não toma peitas, que não se deixa corromper com dinheiro"}

Inseparável do tema da corrupção da República,a condenação do amor excessivo ao dinheiro e às riquezas constituiu um tópico disseminado nos escritos sobre a moralidade das autoridades régias. Presente nos textos jurídicos, o tema da limpeza das mãos como uma virtude essencial àqueles que governam os povos, difunde-se, a partir do século XVI,por uma série de escritos sobre a presença portuguesa na Ásia,da qual o mais conhecido é, sem dúvida, o Soldado Prático, de Diogo do Couto. Responsável por uma das narrativas mais influentes sobre a corrupção moral e política em seu tempo,ele pinta um retrato sombrio e assustador da rapacidade e da venalidade reinantes entre as autoridades que serviam na Índia,particularmente os vice-reis, a quem atribui a causa da decadência daquele estado (Martins, 2001, p. 286). Escrito em dois momentos diferentes, primeiro entre os anos de 1560 a 1570 (Martins, 1985, p. 30) e depois reelaborado sob os reinados de Filipe II e III, o Soldado Prático conta, sob a forma de diálogo, as desventuras de um militar na Índia, tendo como eixo central, como bem apontou Amaral, "as diferentes traças que a ambição dos particulares havia inventado para tirar lucro do Estado da Índia à custa do Estado" (Couto, 1790, p. XII).

Outra obra praticamente contemporânea do Soldado Prático viria engrossar a crítica à corrupção reinante na Ásia. Trata-se de Primor e honra da vida soldadesca. De autoria desconhecida, a obra,escrita em 1578, somente viria à luz em 1630. À semelhança do Soldado Prático, o pequeno texto anônimo tem como ponto de partida a constatação da ruína do Estado da Índia, que o autor imputa à imoralidade e à inexperiência dos governantes portugueses,

${ }^{3} \mathrm{AHU}$, Rio de Janeiro, CA, doc. 1949-1950. Lisboa, 30 out. 1694. 
aos quais faltavam as qualidades necessárias ao comando militar. Essa crítica - o centro gravitacional do texto, por assim dizer - atinge em cheio os critérios de recrutamento dos vice-reis da Índia: escolhidos entre a nobreza portuguesa, privilegiando-se critérios de sangue em detrimento dos de competência ou merecimento, eles careciam de preparo nos negócios militares, sendo os cargos da Índia dados de "olhos fechados" a indivíduos que gozavam de "privanças, aderências e parentes poderosos" . Segundo ele, não se exige nunca a virtude aos que vão governar e o resultado é sempre prejudicial à Coroa: pois como um sapateiro que, com a sua ignorância, pode estragar uma bota, assim também um governante, com sua malícia e ignorância, pode danar um Estado (Primor, 1630, p. 41).

Assim, escolhidos segundo critérios palacianos, os vice-reis da Índia são descritos como viciosos, ávidos por riquezas e tomados por uma "fome canina", pois que partem para a Índia com o único propósito de enriquecer rapidamente. Ali, entregam-se a uma vida luxuosa e dissoluta, voltada para os prazeres carnais e, como verdadeiros mercenários, são homens de "ânimo apoucado e vil", que nada mais buscam do que riquezas, esquecidos da honra e do serviço régio. Nas palavras do autor anônimo, esses governantes ambiciosos "quebram as leis, desrespeitam os regimentos, estragam a Justiça e destroem o Estado" (Primor, 1630, p. 38).

As formulações contidas no Primor e honra da vida soldadesca reapareceriam, à mesma época, quase que in totum, em uma obra escrita também por um ex-soldado, com larga experiência na Índia. Redigida entre os anos de 1620 e 1621, a Reformação da milícia e governo do estado da Índia oriental, de Francisco Rodrigues Silveira (Silveira, 1996), se filia, portanto, à literatura militar sobre a ruína da Índia (Faria, 2012, p. 359). À semelhança das obras anteriores, seu autor pinta um retrato implacável do descalabro administrativo ali reinante, atribuindo aos capitães de armada e fortaleza, e, mesmo, aos vicereis, toda sorte de roubo - situação que Silveira resume em uma frase lapidar: a Índia é "mãe piedosíssima de velhacos e cruel madrasta de homens de bem" (Silveira, 1996, p. 163).

Em comum,essas crônicas identificam na avidez desmedida não só a origem de todas as desordens, mas também a explicação mais convincente para a decadência da Índia,apoiando-se, em grande parte, nos escritos sobre a decadência de Roma. ${ }^{4}$ À condenação da cobiça - que Cassiodoro e Ovídio compararam ao mal da hidropsia, posto que quanto mais se bebe, maior é a sede, jamais encontrando satisfação (Primor, 1630, p. 39v) - e à vituperação das riquezas, contrapõem-se o elogio da virtude e a exaltação da honra, estabelecendo a oposição entre a busca das riquezas e a busca da fama e glória, em uma censura implacável daqueles governantes que, esquecidos da honra, cuidam tão somente de enriquecer, colocando os próprios interesses acima dos

${ }^{4} \mathrm{~A}$ condenação moral da ambição dos que protagonizaram a expansão portuguesa - uma tópica bastante difundida nos autores dos séculos XVI e XVII - ancora-se na idéia de um "codigo ético", cujo fulcro éa denúncia dos que antepunham os próprios interesses aos interesses do bem comum e da Coroa. Ver Silva (2011). 
interesses do monarca. É o tópico do nobre sem honra, aviltado pela cobiça, que o teatro de Molière explorou com tanta ênfase (Cruz, 1998, p. 49). Como tantos outros, Francisco Rodrigues Lobo,em seu Corte na aldeia, de 1619,também deplora a cobiça que esteve na origem da aventura marítima dos portugueses: "romper as entranhas da terra e chegar à vista do inferno por tirar ouro: descer ao fundo do mar por buscar pérolas, descobrir novas regiões, sofrer climas estranhos, e bárbaras gentes para adquirir comércios, obras foram de cobiça, e não de amor, como também o foi a navegação, que na empresa do Velocinio d'ouro começou" (Lobo, 1890, p. 89).

A vontade de enriquecimento, por parte dos governantes, aparece nesses textos como um vício altamente condenável, que, circunscrito à esfera moral, desencadeia efeitos políticos nocivos à Monarquia, pois que nele estão os germens da corrupção da república. Desse modo, é possível interpretar as diatribes dos autores militares contra a ganância dos vice-reis e governadores como a permanência de uma cultura cavalheiresca, sobretudo se se considera o fato de que o universo militar foi tradicionalmente o lugar onde se buscavam a glória e a fama (Maravall, 1948, p. 38). Para Maravall, o advento do Estado moderno baseado na economia monetária assinala o declínio dos valores heroicos da cultura cavalheiresca, e, com ele, o desaparecimento daquela concepção de riqueza e o aparecimento de outra, mais mercantil, esvaziada de conteúdo heroico - e se, a princípio,os moralistas e teólogos vão se insurgir contra essa nova noção, identificando-a à ganância, aos poucos, porém, tal condenação cede lugar à aceitação dos novos tempos (Maravall, 1948, p. 30).

Nesse contexto de transição entre duas mentalidades diferentes,os textos da época foram particularmente sensíveis ao problema da cobiça frente ao código ético da cavalaria. Almejar riquezas não era um defeito em si, e um dos títulos das Siete Partidas nota que "ganho é coisa que naturalmente cobiçam todos os homens e muito mais os que guerreiam" (Maravall, 1972, t. 2, p. 105). Dom Quixote, por exemplo, é animado pela motivação econômica do enriquecimento, mas, como sublinha Maravall, há uma diferença significativa entre ele e seus contemporâneos: no caso do cavaleiro, o que está em jogo não é a acumulação de dinheiro, e sim, a acumulação de "tesouros, terras e de gentes sobre as quais ele é senhor" . Não se reveste da forma puramente mercantil dos tempos modernos a ambição da personagem de Cervantes, mas, ao contrário, é uma forma heroica dos tempos medievais, pois que lhe confere honra e fama, sendo legítima e aceita socialmente (Maravall, 1972, t. 2, p. 106). É o gosto pelas riquezas em si - em seu valor intrínseco - que contraria o código de conduta do cavaleiro virtuoso e honrado. (Maravall, 1948, p. 28). E mesmo a ambição heroica comporta, na moral medieval, algum tipo de limitação, devendo se conformar à posição social dos indivíduos: pretender mais riquezas do que as necessárias para viver de acordo com tal posição é avareza e essa constitui um pecado capital (Maravall, 1972, t. 2, p. 46-62). Também prevalece a convicção de que a legitimidade do desejo de riquezas depende dos merecimentos do indivíduo. Bluteau se refere à ambição como "desejo imoderado de honras não merecidas ou maiores das que merecemos" (Bluteau, 1728, v. 1, p. 325). 
Para Jean Bodin, é arte diabólica distribuir bens, que não estejam em proporção com a capacidade de cada um: assim, "dar riqueza aos pobres, prazer aos aflitos, poder aos fracos, beleza aos feios, conhecimento aos ignorantes e honra aos desprezíveis" são, para ele, artimanhas do diabo (Maravall, 1979, p. 30).

$\mathrm{Na}$ ética cavalheiresca, baseada em um rigoroso código de conduta, a cobiça e a avareza são vícios que os tratados morais condenam reiteradamente,porque se opõem à honra: "o cobiçoso é cego para não ver a razão nem honra e para se abaixar a todas as infâmias a que se sujeita o interesse" (França, 1997, p. 140). Também aí o amor à honra contrasta com a vileza do interesse, o qual determina um uso vicioso e pouco edificante dos bens materiais. $\mathrm{O}$ autor da Corte na Aldeia é quem melhor discorre sobre o consumo nobre,por assim dizer, das riquezas materiais, ao relatar o conselho de um pai ao filho: "que usasse das riquezas como nobre, e favorecesse a velhice de quem o criara, e honrasse aos pequenos irmãos que tinha; que fosse proveitoso aos amigos e parentes; benigno aos pobres e se não cativasse ao trabalho de entesourar riquezas sem fruto" (Lobo, 1890, v. 1, p. 97).

Se a ganância fere o código de valores da cavalaria, sendo um comportamento indigno dos nobres,é tanto mais nociva quando encontrada nos indivíduos a quem compete o governo dos povos (Brunke, 2006, p. 134-136). Esse é um tema influente nos escritos políticos e morais da Época Moderna: Saavedra Fajardo, por exemplo, diz: “Ó infeliz o Príncipe e o Estado que se perdem porque se enriquecem seus ministros" (Fajardo, 1985, p. 385). Castillo de Bovadilla distingue, com base em Cícero e nos textos bíblicos, dois tipos de cobiça nos governantes: a "ordenada cobiça", que é a pretensão de fazenda e fama, "que não somente não é reprovada, nem viciosa, mas digna de ter por egrégia virtude, e providência", pois que é necessária para a magnanimidade do corregedor." Contrária à ela, a má cobiça, que é "abominável e perniciosa”, pois que "o vício mais pestilencial e nocivo, assim para eles [juízes e governadores] como para os súditos, a qual o profeta Joel comparou à embriaguez, porque nenhum vinho embriaga, nem obscurece, nem anuvia o entendimento, tanto como a cobiça" (Bovadilla, 1775, livro II, p. 437). É o enriquecimento proporcionado pela ordenada cobiça que permite o exercício das virtudes da liberalidade e da caridade. E, de fato,nos espelhos de príncipe,o bom governante é aquele que prefere destinar as suas riquezas aos pobres e necessitados, em vez de simplesmente guardá-las e acumulá-las, como se vê em uma passagem da Crônica da Tomada de Ceuta, onde Gomes Eanes de Zurara conta que a santa rainha Dona Felipa,à beira da morte,distribuiu parte dos seus bens aos necessitados: "cá sua riqueza toda era tesouro de pobres, fazendo muitas esmolas [. . ] assim para casar órfãs e criar meninos" (Queirós, 1997, p. 114).

À "ordenada cobiça", própria dos nobres,opõe-se a pobreza - considerada por alguns como a origem dos vícios, pois como diz o autor do Libro del consejo y de los consejeros: "a míngua das coisas temporais" envilece a condição dos homens. (Maravall, 1972, t. 2, p. 105). A detração da pobreza - como nas Siete 
Partidas, onde se diz que "a pobreza conduz os homens à grande cobiça, que é raiz de todo mal" - vai inspirar uma vertente que sustentará que os funcionários não devem ser pobres (Bovadilla, livro II, p. 147). Em sua Miscellanea, publicada em Portugal em 1628, Miguel Leitão de Andrada — para quem "qual vil cousa seja a pobreza, e a quantas vilezas obrigue todas alheias da nobreza" - se oporá a escolha de homens pobres para a ocupação de cargos e postos, citando Isaías - " se em minha casa não há pão, nem vestido, não me queiras fazer governador do povo” - e Tucídides - segundo quem os atenienses praticavam a lei de Sólon, que proibia os pobres de terem cargo, para não usarem mal dele (Andrada, 1867, p. 399).

\section{"Ó infeliz o Príncipe e o Estado que se perdem porque se enriquecem seus ministros"}

Há, pois, que evitar tanto a pobreza - da qual nasce a má ambição quanto a cobiça desenfreada - que, na Época Moderna, se designa mais frequentemente por avareza, entendida, conforme Bluteau, pelo "demasiado amor das riquezas" (Bluteau, 1728, v. 1, p. 656). Os conceitos de avareza e o seu oposto - a liberalidade - estão inextricavelmente ligados na literatura política e moral da Época Moderna, especialmente nos espelhos de príncipe escritos na Península Ibérica, entre os séculos XV e XVI. O autor do já citado Libro del Consejo e de los consejeros identifica a cobiça como um dos vícios que impedem um homem de ser um bom conselheiro (Muniz, 2005, p. 20). Em seu Leal Conselheiro, escrito na primeira metade do século XV,D. Duarte nota que a liberalidade é o oposto da avareza, observando que "havendo-se como convém e possuindo liberalidade, que é uma virtude, posta e declarada nas Éticas de Aristóteles e outros muitos livros, entre a escassez e o sobejo de gastar" (Sousa, 2013, p. 70). Esperava-se que os representantes do rei manifestassem tal espírito liberal,mostrando-se dispostos a renunciar aos próprios bens em proveito da monarquia,pois servi-la implicava sacrificar riquezas e vidas em seu nome,o que constituía prova inequívoca de lealdade - nas palavras de Sebastião César de Menezes,"as ações generosas sustentam e dilatam os Impérios" (Menezes, 1650, p. 58). A essas virtudes correspondem, em chave oposta,os vícios da prodigalidade e da avareza: a primeira é quando se dá o que se deve e o que não se deve, nada ficando para si; a segunda, quando não se dá o que se deve dar, guardando tudo para si. Além da Ética de Aristóteles, uma das fontes de condenação da ambição e da avareza dos governantes situava-se nos textos de Cícero. É assim, por exemplo, que Diogo Lopes Rebelo, o mais antigo tratadista ibérico no campo do direito político, comenta, em seu livro De Republica Gubernanda per Regem, de 1496, que, entre os vícios opostos à liberalidade, o pior é a avareza, e glosando o pensador romano, conclui que "não há vício mais repugnante do que a avareza, sobretudo nos príncipes e nos governantes da república" . Assim como o príncipe deve afastar-se desse 
vício, "compete-lhe, também, proibir os juízes e governadores (...) de aceitarem dádivas, no julgamento dos processos e na administração da justiça. (...) Não recebas presentes, porque eles cegam os olhos dos sábios e alteram o peso da justiça". Ao rei, cabe conhecer, com o maior cuidado, se os seus juízes são vulneráveis ao vício da avareza (Mesquita, 2004, p. 14).

Herdeiro dessas concepções, Diogo do Couto afirma que a avareza é um vício que assola particularmente a Índia,distinguindo-a da liberalidade,que é "usar moderadamente das riquezas (...); pelo contrário, a avareza é um apetite desordenado, uma cobiça insaciável e uma enfermidade que abrange a todas às partes do corpo..." (Couto, 1790, p. 116). Na obra Summa Politica,Sebastião César de Menezes sublinha que uma das obrigações do príncipe consiste na "boa eleição de ministros", graças à qual se podia evitar as queixas dos vassalos,uma vez que dessas nasciam graves e sérios perigos para a República. Em suas palavras, o ministro desprovido das qualidades necessárias ao governo, "desacredita o Príncipe, pela eleição,desautoriza o lugar,pela pessoa;e arruína os estado,pelo governo" (Menezes, 1650, p. 158).

Na cultura política dos vassalos americanos, o tema da avareza ou da ambição desmedida dos governantes aparece com frequência associada à reivindicação de uma escolha mais cuidadosa por parte do rei. Assim, em 1661, o provedor-mor da Fazenda do Estado do Brasil, Lourenço de Brito Correia, escreveu ao rei, pedindo que enviasse para a América bons ministros, "para que tudo não seja tirania, interesses, e aumento da fazenda própria, em grande prejuízo dos vassalos de Vossa Majestade". Em termos muito parecidos,a câmara do Rio de Janeiro assim se dirige ao monarca:"pela glória de seu trono, felicidade e amparo dos vassalos, pede e clama seja servido dar eficazes providências na escolha de homens para o governo desta terra" (Coaracy, 1965, p. 27). Parece,então,ser uma convicção arraigada,mesmo entre os membros do Conselho Ultramarino,que os ministros enviados para as conquistas do Novo Mundo têm por único propósito o enriquecimento ilícito. O lúcido e experiente Antônio Rodrigues da Costa escreve,em uma consulta de 1721,que "os governadores que se lhe mandam [para o Brasil], ministros e oficiais [...] vão cheios de ambição, e o seu principal objeto é enriquecerem-se, valendo-se para isto de todos os meios lícitos e ilícitos." Em um manifesto de 1700, assinado por um tal de "Engenho do Rio de Janeiro", o autor desabafa que os ministros nomeados pelo rei têm por máxima "venha para cá o ouro de sua majestade que lhe queremos pôr a mão por cima, e os bugios do Brasil que se esfolem [...]" (Figueiredo, 2003, p. 11-12).

Se a nobreza pode ser adquirida através da virtude, ela também pode ser perdida através do vício,particularmente do vício da cobiça. Um dos principais representantes do humanismo político português, Jerônimo Osório da Fonseca, autor de Tratados de Nobreza Civil e Cristã, publicado pela primeira vez em 1542, nota que "merecem grandemente a geral execração e ódio quantos aniquilam a nomeada que herdaram, manchando-se com a indignidade" (Toledo, 2006, p. 76). A nobreza comporta, afinal, uma dimensão ética: se na teoria platônica, amplamente apropriada pelos tratadistas nobiliários ibéricos, identifica-se o 
nobre ao bom e ao belo, associando-o assim à virtude e à honra, impunha ao nobre um comportamento exemplar, verdadeiro modelo que todos deveriam imitar (Berrendero, 2011, p. 117). Ou seja, os verdadeiros nobres são aqueles que respeitam as leis de Deus, do rei e dos homens, mantendo-se distantes de vícios como a ambição, a avareza, a cólera e a soberba, adotando um comportamento virtuoso, compatível com a sua posição na sociedade (Maravall, 1979, p. 36). A esse respeito, Bluteau observa que a nobreza - fosse hereditária ou política - destituída da virtude não passa de uma "fútil ostentação de fantástica grandeza." (Bluteau, 1728, v. 5, p. 732). A crítica daqueles que não se comportam de acordo com a nobreza exigida pelo seu lugar social será objeto da literatura moralista dos séculos XVI e XVII, que condenará o nobre que negligencia os seus deveres para com a religião, com a lei e a virtude. Nas Cartas Chilenas, as invectivas de Critilo contra a rapacidade do Fanfarrão Minésio repousam precisamente na ideia de que o seu comportamento vicioso não é digno de um nobre (Gonzaga, Carta $1^{\mathrm{a}}$ ). É, portanto,dessa perspectiva que se formula a condenação da ambição desmedida dos governantes — tal como aparece nos autores aqui examinados que, esquecidos de suas obrigações morais, entregam-se aos vícios, ou ainda a crítica aos que enriquecem de forma ilícita - "a riqueza mal adquirida" - um tema dos discursos moralistas, a exemplo de Miguel Leitão, para quem “[a riqueza] mal adquirida, confesso não somente não merecer ser nobreza, mas nem ainda outra honra, ou privilégio algum, como o dizem todos os doutores." (Andrada, 1867, p. 398).

Para grande parte desses autores militares, os critérios de virtude e merecimento não são, por si só, suficientes para impedir os abusos dos governantes; por essa razão, advogam a criação de mecanismos mais eficientes de controle e punição. Contudo, a ideia de que ocupantes de determinados cargos e postos tivessem que se submeter a um tipo de inspeção nem sempre encontrou acolhida. Um exemplo é a oposição, na Espanha do século XVI, às medidas de Felipe II acerca da vigilância sobre os vice-reis de Nápoles, Sicília e Milão, por meio de visitas gerais, cujo objetivo era "saber como os oficiais tinham se havido no uso de seus ofícios, para castigar aos que se acharem culpados e fazer mercê aos que bem serviram." Como mostra Rodríguez, muitos se insurgiram contra tal novidade, alegando que impor algum tipo de controle sobre esses homens, equivalia a reduzi-los à condição pouco digna de oficiais, ou seja, a meros executores da vontade real, o que era incompatível com a estimação da nobreza; reivindicavam, ao contrário,um mandato livre,cuja dignidade não admitia limitações - posto que "quem representa a pessoa de Suma Majestade convém que tenha inteira autoridade e que não possa estar sujeito a um risco de tanto descrédito para o seu decoro" (Rodríguez, 2011, p. 100-102).

Para Chabod, a resistência dos vice-reis espanhóis a uma concepção burocrática de seu ofício põe em evidência o fato de que permaneciam presos a um "código de honra pessoal e do serviço inscrito na ética cavalheiresca" (Chabod, 1958, p. 181). Para esses homens, a concessão do cargo decorria dos seus vínculos pessoais com o soberano, e, ao assumi-lo,tornavam-se membros de sua família, pois que, em sua condição de nobres, zelariam pela dignidade do cargo. 
Nisso, diziam,contrastavam com os demais oficiais, e Juan de Vega assim se manifestou contra os que haviam proposto a subordinação dos vice-reis ao rei:

"são homens baixos e ambiciosos, que se criaram baixamente, e que não sabem que coisa é ser Rei, nem em que está a Grandeza, nem a autoridade do Rei, nem as províncias do mundo e qualidades da gente, nem cavalaria, nem honra, nem grandeza e Estados dos que merecemos ser vice-reis, nem como hão de ser esses, nem o capitão general e outros ministros desta qualidade" (Rodríguez, 2011, p. 100).

Por outro lado, a concepção do ofício como uma dádiva,expressão de um vínculo especial com o monarca,ofício que se ocupa como alter ego dele,favorecia uma atitude baseada na fidelidade pessoal,que se manifestava no ato de colocar à disposição do monarca os próprios bens, prestígio e honra, oferecendo-os como uma reserva para a Coroa.

Apesar de estarem sujeitos aos juicios de residencia, os vice-reis na América se conduziram com grande autonomia e independência, justificada frequentemente pelo argumento de que estavam submetidos tão-somente à lealdade pessoal ao soberano. Em Portugal, porém, os vice-reis jamais reivindicaram essa prerrogativa, estando sujeitos aos mesmos mecanismos de controle - como as residências e devassas - aplicáveis aos demais funcionários régios, sem que existissem diferenças significativas entre eles e os governadores. (Cunha; Monteiro, 1994, p. 176). Ainda que a distinção entre persona real e "alto funcionário" - tão presente nos debates sobre os limites da autonomia dos vice-reis da Monarquia hispânica - estivesse ausente das reflexões sobre as autoridades do Império português, é inegável a influência dessas concepções derivadas da ética cavalheiresca na forma como concebiam a própria atuação.

No centro das formulações dos autores empenhados em refletir sobre a corrupção da República, está a noção de bem comum,em consonância com os escritos de Vitoria, Domingo de Soto, Belarmino, Suárez, entre outros. Mas se os pensadores da Segunda Escolástica foram buscá-la em São Tomás,o certo é que nas teorias políticas da Época Moderna fixou-se a opinião de que o bem comum constituía a suprema finalidade do governo (Maravall, 1972, t. 2, p. 209). E o bem comum não excluía o bem particular dos vassalos, como se vê no Primor e honra,cujo autor nota que o tirano, dominado pela "entranhável cobiça", esquece-se de que "o que for proveitoso para o bem comum, converterá em seu particular interesse" (Primor, 1630, p. 39v). É ainda o bem comum que deve pautar o serviço régio, que, como uma relação entre pai e filho, visa ao "aumento do Estado e proveito e utilidade universal dos vassalos," como explicou o autor da Reformação (Silveira, 1996, p. 181).

Se a noção do bem comum remete ao ideal do bom governo, assentado em "bem comum/justiça/governo justo/saúde do corpo místico", a noção de bem particular alude à corrupção: "bem particular/injustiça/tirania/corrupção do corpo místico". Tirano é, pois, o nome que se dá ao príncipe e a todo aquele que, a serviço dele,padece do vício da avareza - como dizia Petrarca, 
é o "proprium commodum" que decorre da avaritia (Capelli, 2008, p. 101-102). Segundo Capelli e Ramos, no pensamento grego, e, mais ainda, no romano, já se achava definida tipologicamente a oposição entre o governante virtuoso e o tirano, sendo este aquele que, ou pela forma de aquisição, ou pelo exercício do poder, violenta as regras de um governo justo, dando lugar à violência e à prevalência do interesse particular sobre o interesse público (Capelli, 2008, p. 10). Esta tipologia, para a qual confluiu também a tradição cristã, permanecerá estável ao longo da Idade Média e do Renascimento, consolidando o conceito de tirano como "aquele que exerce o poder em desacordo com seus fins de justiça e virtude" (Maravall, 1944,p. 400). O humanismo político, por exemplo, situará nos textos de Cícero sobre a ilicitude do sui commodun (interesse privado) a chave para a reflexão sobre a tirania, conferindo-lhe uma dimensão mais propriamente econômica, como adverte Coluccio Salutati,pois que, nos casos de tirania,

"os bens e os ganhos da república ficam à disposição do arbítrio de quem não considera a utilidade dos súditos, senão a sua própria (...) se enriquece com o sofrimento dos pobres cidadãos e o que deveria ser distribuído para utilidade de todos, fica submetido, de forma injusta,à avareza e à rapacidade de um só" (Capelli, 2008, p. 102).

\section{Se a noção do bem comum remete ao ideal do bom governo, assentado em "bem comum/justiça/governo justo/saúde do corpo místico”, a noção de bem particular alude à corrupção}

O conceito de tirania está no centro da cultura filosófico-jurídica que floresceu na Península Ibérica no século XVII, particularmente nas teorias corporativas de poder, a exemplo da obra Defensio Fidei, de Francisco Suárez, que herda a distinção clássica entre tirania de origem e a tirania de exercício. Esta última será por ele definida como o governante legítimo que abusa de seu poder: tirano é "aquele que converte tudo em seu próprio proveito com desprezo do bem público," ou aquele que "aflige injustamente a seus súditos pelo roubo, pelo homicídio, pela corrupção e outros feitos similares" (Maravall, 1944, p. 404). Do mesmo modo, Francisco de Vitória escreverá sobre a lei que não atende ao bem comum: "seria uma lei tirânica,não uma lei justa,posto que se trata de uma pessoa pública,que está ordenada ao bem comum” (Vitoria, 1994, p. 6)

Cumpre chamar a atenção para a emergência, no século XVII, de uma formulação renovada sobre a tirania, inspirada na noção de "tirania velada ou tácita”, elaborada por Bartolo de Sassoferrato, e que consiste naquela em que incorre o rei, quando,por negligência ou indiferença, "deixa atuar com excessivo poder a um servidor seu, a um ministro ou valido particular." Neste caso, o tirano é o próprio monarca, cujo defeito reside no abandono - e não 
no excesso - de poder,pois que,como escreve Maravall, "o dever de obrar em determinada medida é tão determinante como o de não obrar mais além destes mesmos limites, e seu desconhecimento dá lugar analogamente a uma situação de tirania" (Maravall, 1944, p. 404). A ideia de que os excessos das autoridades nascem da inércia ou indiferença do príncipe - a quem competia, em última instância,a responsabilidade por eles - circulava nos escritos dos autores militares dos séculos XVI e XVII. Diogo do Couto,por exemplo,não hesitou em identificar a origem das violências cometidas pelos governadores: em suas palavras, "a culpa ponho aos reis" (Couto, 1790, p. 9). E isso por três razões relacionadas entre si: em primeiro lugar, a grande autonomia conferida por ele aos seus representantes, os quais seguiam para a Índia, com a ordem expressa de "que sobre tudo façais o que vos parecer mais meu serviço" ; em segundo lugar, a impunidade de que gozavam aqueles, dado que os mecanismos de controle, como as devassas e residências, eram inócuos, posto que as testemunhas depunham sob coação. E, finalmente, a razão mais perturbadora: a ignorância deliberada do rei sobre o que se passava em seus domínios. Afinal, lembrava Diogo do Couto,ainda que não pudesse ver tudo, não faltavam pessoas práticas e experientes que "lhe fale verdade nestas cousas" (Couto, 1790, p. 9). Dessa passividade, de que nascia a iniquidade - e da qual fazia parte também ignorar as queixas dos vassalos distantes —, os reis haveriam de prestar contas a Deus: "sabeis de que me escandalizo é de que os reis hão de dar grande conta a Deus?" (Couto, 1790, p. 70).

Grande parte dos autores que associaram a decadência da Índia à corrupção generalizada dos quadros administrativos,eram partidários de uma concepção organicista da República,na qual,segundo o autor de Primor e honra, assim como a "cabeça - o rei - se sustenta do corpo, e o corpo da cabeça", assim também o serviço régio sustenta toda a República,do que se conclui que a atuação viciosa dos funcionários faz corromper todo o corpo, pois que perverte as finalidades do bem comum e da felicidade dos povos (Primor, 1630, p. 35). É essa concepção da República como corpo, derivada das teorias corporativas de poder,que dá sentido ao conceito de corrupção como metáfora para a degradação física. Daí a proliferação de termos ligados ao campo médico: em Diogo do Couto, "já na Índia não há cousa sã; tudo está podre e afistulado, e muito perto de herpes, se se não cortar um membro, virá a enfermar todo o corpo, e a corromper-se" (Couto, 1790, p. 57). Em Francisco Silveira, quando se refere à "perigosa enfermidade", cujo remédio pretende apontar, ou ainda, quando alude ao "corpo enfermo de Portugal", do qual é preciso "cortar-lhe o membro podre e corrupto de nossa Índia, para que de todo se não acabe de infeccionar com ela, e que permita perder-se aquela província, para que esta outra que mais importa, se salve" (Silveira, 1996, p. 200).

Âmago das reflexões desses autores, a corrupção do corpo místico não só comportava uma definição rigorosa e clara - elaborada a partir de um conjunto de textos bíblicos e clássicos —, mas também possuía um vocabulário específico, extraído da esfera médica,do qual faziam parte termos como enfermidade, infeccionar, apodrecer, curar, sarar, membro, amputar, remédio. Mas 
a esfera médica estava longe de esgotar o universo das metáforas relativas ao conceito de corrupção. Assim,por exemplo, para descrever a ação do governante que enriquece às custas do Estado e dos vassalos, recorria-se a verbos como chupar e sugar - que remetem à metáfora da esponja -;a verbos como esfolar,desfolhar,vindimar,largar;ou, ainda, a determinadas imagens como a ave de rapina e a harpia- e seus correlatos, como garra, unha e hárpeo. Se a corrupção - como o efeito de práticas viciosas e não as práticas em si - é a defraudação do Estado - entendida como os bens do monarca - , ela é,sobretudo, o roubo cometido contra os mais pobres, as principais vítimas dos governantes cobiçosos. Nas palavras de Vieira,o ganho ilícito nasce "das lágrimas do miserável e dos suores do pobre, que não sei como atura já tanto a constância e fidelidade destes vassalos" (Vieira, 1998; Villalta, 2015, p. 68). Trata-se da velha tópica - possivelmente oriunda de uma certa tradição cristã — segundo a qual a riqueza de uns se faz por meio da pobreza de outros, e que opõe, de um lado, o rico que suga, e, de outro, o pobre sugado. Se a pobreza deve suscitar a compaixão e a misericórdia - pois que ela resulta, como dizia Manuel Álvares Pegado,da "injustiça da sorte” (Hespanha, 2010, p. 234)— , obrigando o bom cristão à caridade e à piedade,o mau governante é também aquele que não ama a Deus nem ao próximo. Roubar ao pobre é,portanto,a perversão da caridade - e esta,à semelhança das demais virtudes cristãs, consiste numa qualidade necessária aos governantes, como se vê na sentença final de um governador do Rio de Janeiro: "fora muito compassivo dos pobres, com as quais dispendera muito de sua fazenda, por cujas virtudes afirmam fora o sindicado um dos melhores governadores que passaram àquela praça $(. . .)^{\prime \prime}$

\section{Roubar ao pobre é, portanto, a perversão da caridade - e esta, à semelhança das demais virtudes cristãs, consiste numa qualidade necessária aos governantes}

Modelo paradigmático do governante que suga o sangue dos pobres para convertê-lo na própria riqueza é o faraó do Egito, responsável pelo cativeiro do povo hebreu - para Vieira,ele personifica a tirania:

"El-rei Faraó tinha cativo o povo de Israel no Egito, e com o mais duro e intolerável cativeiro que se pode imaginar. Não lhes pagava o trabalho, antes lho acrescentava cada dia, para que não tivessem hora de descanso; punha-lhes por ministros, que superintendessem as obras em que serviam, os de condição áspera e cruel, para que mais os oprimissem. Não lhe dava de comer com que sustentar a miserável vida, e até os filhos lhes matava cautelosamente, sem que os pudessem esconder nem livrar. Enfim, o sumo da tirania" (Vieira,1965, v. 1).

${ }^{5} \mathrm{AHU}$, Rio de Janeiro, CA, doc. 1949-1950. Lisboa, 30 out. 1694. 
O faraó como modelo de tirania — além de tirano, também pagão — encontra-se, por exemplo, em São Tomás de Aquino, que, em seu Do Reino ou governo dos príncipes ao rei de Chipre compendia as passagens do Êxodo, Deuteronômio e Isaías para descrever a conduta do faraó (Aquino, 1995, p. 141-142). Aliás, tal analogia não ficou restrita ao mundo católico. No século XVI,por exemplo,os holandeses interpretaram o domínio espanhol a partir da narrativa do Antigo Testamento sobre a fuga dos hebreus do Egito: a epopeia do Êxodo proporcionou-lhes uma referência para a ruptura com um passado de sofrimento e opressão, no qual o rei Filipe II da Espanha figurava como o faraó que havia tiranizado os judeus bíblicos - "um prostrava a casa de Jacó com escravidão/ O outro, os Países Baixos, com tirania" (Schama, 1992, p. 120).

Se a história antiga,extraída tanto das narrativas bíblicas quanto dos autores clássicos, forneceu uma vasta galeria de déspotas para ilustrar o conceito de tirania,foi,sem dúvida, a história de Roma que proporcionou, na Época Moderna,uma das referências centrais para o problema da corrupção resultante da atuação ilícita dos funcionários. Vieira, por exemplo, pregará que "enquanto os romanos guardaram igualdade, ainda que neles não era verdadeira virtude,floresceu seu império, e foram senhores do mundo; porém,tanto que a inteireza da justiça se foi corrompendo pouco a pouco, ao mesmo passo enfraqueceram as forças... " (Vieira, 1998). Santo Agostinho, Cipião Africano, Políbio, Salústio, Tácito e Tito Lívio foram alguns dos pensadores que demarcaram o campo de reflexão política sobre a relação entre corrupção e decadência. E não é por outro motivo que Nero e Calígula figuram nos escritos políticos da época,como os principais modelos do mau governante, ao lado do faraó do Egito.

Nos textos de Francisco Suárez, Nero é o exemplo por excelência do tyrannus a regimine, ou seja, daquele que seja porque "converte tudo em seu próprio proveito, com desprezo do bem público", seja porque "ou que aflige injustamente a seus súditos pelo roubo, pelo homicídio, pela corrupção e outros feitos similares" (Robledo, 1989, p. 68). Quase 200 anos depois,o tópico permanecerá vigoroso: nas Cartas Chilenas, Critilo compara o Fanfarrão Minésio a Nero (Gonzaga, Carta 2a . ); poucos anos antes, os pasquins que circularam por ocasião da Inconfidência do Curvelo, associavam o rei D. José I a Nero, "outro, ou pior que Nero que por estar demente, ou pateta” (Catão, 2005, p. 18).

\section{Considerações finais}

É, afinal,possível falar em corrupção nas sociedades da Época Moderna,sem incorrer em anacronismo? Ao longo dessa exposição, argumentou-se que não só o conceito estava firmemente consolidado na cultura política da época,mas também se ancorava em um repertório bem definido de tópicas e formulações, assentado em textos antigos e bíblicos. Além disso,o conceito também remetia para um vocabulário específico,tributário, em parte,da esfera médica, e dos escritos sobre o bom governo da tradição clássica. Evidentemente,um abismo separa as noções contemporâneas sobre a corrupção daquelas analisadas aqui. 
A começar pelo fato de que a esfera política não estava separada da esfera religiosa,a qual se subordinava. Mais do que uma questão estritamente política,a corrupção constituía, na cultura política da Época Moderna,um problema moral de natureza individual que afetava a saúde da República.

A condenação das práticas tidas por ilícitas,dentre as quais o enriquecimento ilegítimo,pode ser rastreada tanto nos escritos político-morais quanto nos textos que orientavam a atuação dos funcionários régios. No entanto,esse conjunto de prescrições esbarrava nas concepções derivadas da ética cavalheiresca, baseadas na ideia de um vínculo estritamente pessoal entre o funcionário e o monarca,mediado por valores como honra e lealdade.

Entretanto, constatar a existência de textos de natureza normativo-legal que caracterizaram a corrupção como um delito pouco elucida o problema. Afinal, apesar do esforço de conceptualização nos textos jurídicos, no sentido de se estabelecer com rigor as fronteiras entre o lícito e o ilícito,um abismo imenso os separava da realidade social,caracterizada pela preeminência das relações pessoais,tanto aquelas em linha direta - família e compadrio - , quanto aquelas em linha vertical - como a clientela,o patronato, o paternalismo (Pietschmann, 1998, p. 48). Na prática, a imputação de uma conduta viciosa e iníqua dependia, em última instância, da inserção do indivíduo nessa complexa trama social - como, aliás, mostram os estudos de Ernst Pijning (Pijning, 1997, 2001) e Zacarias Moutoukias (Moutoukias, 1988).

Por fim,outra consideração a relativizar o peso das normas jurídicas que caracterizavam determinados comportamentos como ilícitos é o fato de que, não obstante a série de proibições e sanções impostas aos infratores, uma série de mecanismos emanados pela Coroa não só favorecia uma imensa tolerância,mas também estimulava os funcionários a recorrer a práticas tidas por ilegais - a exemplo do pagamento de baixos salários,compensados pela participação em negócios clandestinos.

Condenação,repressão,tolerância e favorecimento e estímulo - é em torno dessas noções, aparentemente contraditórias e excludentes, que os sentidos da corrupção na Época Moderna devem ser elucidados.

\section{Referências bibliográficas}

ALONSO, Benjamin González. El Conde Duque de Olivares y la administración de su tiempo. In: SANZ, Ángel García; ELLIOTT,John H. (coord. ). La España del Conde Duque de Olivares Encuentro Internacional sobre la España del Conde Duque de Olivares. Valladolid:Universidad de Valladolid, 1990,p. 275-315.

ANDRADA, Miguel Leitão de. Miscellanea. Lisboa:Imprensa Nacional, 1867.

AQUINO,Tomás de. Escritos políticos de São Tomás de Aquino. Petrópolis:Vozes, 1995.

ARANCIVIA, Eduardo Torres. "El problema historiográfico de la corrupción en el Antiguo Régimen — una tentativa de solución.” Summa Humanitatis. Revista eletrônica, Pontificia Universidad Catolica do Peru, v. 1, n. 0, Lima, 2007, p. 1-33.

BERRENDERO, José Antonio. "Interpretaciones del héroe clásico: La genealogía de la idea de noble/honrado y su desarrollo en la tratadística nobiliaria lusocastellana (1556-1640)". Ágora. Estudos Clássicos em Debate, n. 13, 2011, p. 111-143. 
BERTRAND, Michel. Grandeur et misère de l'office - les officiers de finances de NouvelleEspagne, XVIIe-XVIIIe siècles. Paris: Publications de la Sorbonne, 1999.

BLUTEAU, Raphael. Vocabulario portuguez \& latino: aulico, anatomico, architectonico ... Coimbra: Collegio das Artes da Companhia de Jesu, 1712 - 1728. 8 v.

BOVADILLA, Castillo de. Política para corregidores y señores de vasallos, en tiempo de paz, y de guerra, para prelados en lo espiritual, y temporal, entre legos, jueces de comisión, regidores, abogados, y otros oficiales públicos: y las jurisdicciones, preeminencias, residencias, y salarios de ellos; y de lo tocante a las Ordenes, y Caballeros de ellas. Madrid: Imprensa Real de la Gazeta, 1775.

BRUNKE, José de la Puente. "Codicia y bien público - los ministros de la Audiencia en la Lima seiscentista” . Revista de Indias, v. LXVI, n. 236, Madrid, 2006, p. 133-148.

CAPPELLI, Guido. La otra cara del poder — virtud y legitimidad en el humanismo político. In:CAPPELLI, Guido \& RAMOS, Antonio Gómez (org. ). Tiranía - aproximaciones a una figura del poder. Madrid: Dykinson, 2008, p. 97-120.

CATÃO, Leandro Pena. Sacrílegas palavras - Inconfidência e presença jesuítica nas Minas Gerais durante o período pombalino. Tese (doutorado em História),Universidade Federal de Minas Gerais. Belo Horizonte, 2005.

CHABOD, Federico. Usi e abusi nell’ amministrazione dello Stato di Milano a mezzo il ‘500. In Studici storici in onore di G. Volpe. Florence, 1958,, p. 95-194.

COARACY, Vivaldo. O Rio de Janeiro no século dezessete. Rio de Janeiro: J. Olympio, 1965.

COUTO, Diogo do. Observações sobre as principais causas da decadência dos portugueses na Ásia, escriptas por Diogo do Couto, em forma de diálogo com o título de Soldado Prático publicadas de ordem da Academia Real das Sciencias de Lisboa, por Antônio Caetano do Amaral. Lisboa: Officina da Academia Real das Sciencias, 1790.

CRUZ, Maria Leonor García da Cruz. Os "fumos da Índia" - uma leitura crítica da expansão portuguesa. Lisboa: Cosmos, 1998.

CUNHA,Mafalda Soares da; MONTEIRO, Nuno Gonçalo. Vice-reis e governadores do Estado da Índia: Uma abordagem prosopográfica (1505 - 1834). In:Encontro sobre Portugal e a Índia. Lisboa:Horizonte/ Fundação Oriente, 2000, p. 175-185.

DICKINSON, John. Death of a Republic - Politics and Political Thought at Rome (59-44 B. C. ). New York: Mc Millan Company, 1963.

FAJARDO, Diego Saavedra. Idea un principe politico-cristiano representada en cien empresas. Murcia: Academia Alfonso X El Sabio, 1985.

FARIA, Patrícia Souza de. "Mais soldados e menos padres: remédios para a preservação do Estado da Índia (1629-1636)” . História Unisinos, vol. 16, n. 3,setembro/dezembro de 2012

FIGUEIREDO, Luciano. "Narrativas das rebeliões - linguagem política e idéias radicais na América Portuguesa moderna.” Revista USP, n. 57. São Paulo, março/maio 2003, p. 6-27.

FOUCAULT, Michel. Microfísica do poder. Organização, introdução e Revisão Técnica de Roberto Machado. Rio de Janeiro: Graal, 1982.

FRANÇA. Eduardo D’Oliveira. Portugal na época da Restauração. São Paulo: Hucitec, 1997. FURETIÈRE, Antoine. Dictionnaire de l'Académie Française, Paris:Vve Coignard/J. -B. Coignard, 1694, vol 2. Disponível em: http://artflsrv01. uchicago. edu.

GONZAGA, Tomás Antônio. Cartas Chilenas. Belém: Universidade da Amazônia, s/d. Disponível em: www. dominiopublico. gov. br. Acesso em: 14 de jun. 2013.

GUTIÉRREZ, Salvador Cárdenas. "La lucha contra la corrupción en la Nueva España según la visión de los Neoestoicos.” Historia Mexicana, vol. LV, n. 3, México, enero-marzo, 2006, p. 717-765. HESPANHA, Antonio Manuel. Imbecillitas: as bem-aventuranças da inferioridade nas sociedades de Antigo Regime. São Paulo: Annablume, 2010.

LEIVA, Pilar Ponce. "Séneca en los Andes. Neoestoicismo y crítica social en Quito a fines del siglo XVII." Historica — revista del Departamento de Humanidades de la Pontificia Universidad Católica del Peru, v. 31, n. 2, Lima, 2007, p. 43-68.

LOBO, Francisco Rodrigues. Corte na aldeia e noites de inverno, vol. 1, diálogo VI. Lisboa:Companhia Nacional, 1890.

MARAVALL, José Antonio. El humanismo de las armas en don Quijote. Madrid: Instituto de Estudios Políticos, 1948.

MARAVALL, José Antonio. Estado Moderno y mentalidad social - siglos XV a XVII. Madrid: Ediciones Revista de Occidente, 1972, 2 tomos. 
MARAVALL, José Antônio. La teoria española del estado en el siglo XVII. Madrid: Instituto de Estudios Políticos, 1944.

MARAVALL, José Antonio. Poder, honor y élites en el siglo XVII. Madrid: Siglo Veintiuno, 1979. MARIA,Theobaldo de Jesus. Agricultor instruido com as prevençoens necessarias para annos futuros, recupilado de graves autores e dividido em tres partes; na primeira se trata das sementeiras, virtudes das sementes, e de comose prezervaraõ da corrupçaõ; na segunda dos arvoredos, e vinhas; Breve tratado da cultura dos jardins; na terceira de todo o gado maior; e menor; e mais animaes domesticos, suas virtudes, e cura de suas infermidades, e das colméas. Etc. / pelo P M Fr Theobaldo de Jsu Maria. [Lisboa], [s. n. ]. 1730.

MARTINS, Antônio Coimbra. Em torno de Diogo do Couto. Coimbra: Biblioteca Geral da Universidade de Coimbra, 1985.

MARTINS, Antônio Coimbra . O Primeiro Soldado Prático. Introdução e Edição do autor. Lisboa: Comissão Nacional para as Comemorações dos Descobrimentos Portugueses, 2001.

MENEZES, Sebastião César. Summa Politica. Amsterdam: Tipographia de Simão Dias Soeiro Luzitano, 1650.

MESQUITA, Amílcar. Diogo Lopes Rebelo e o De Republica gubernanda per regem. Real Monasterio de El Escorial la Ciudad de Dios, 218, p. 189-209. Disponível em: http://repositorio. uportu. pt/ jspui/handle/123456789/375. Acesso em: 15 de jun. 2015.

MOUTOUKIAS, Zacarias. Contrabando y controle colonial en el siglo XVII. Buenos Aires: Centro Editor de America Latina, 1988.

MOUTOUKIAS, Zacarías. Power, corruption, and commerce: the making of the local Administrative Structure in Seventeenth-Century Buenos Aires. Hispanic American Historical Review, v. 68, n. 4, november,1988, p. 771-801.

MUNIZ, Márcio Ricardo Coelho. "Espelho de conselheiros - um possível gênero da literatura política ibérica.” Floema. Caderno de Teoria e História Literária, n. 2, 2005,p. . 101-134.

NICOT,Jean. Thresor de la langue françoyse, tant ancienne que moderne. Paris: David Douceur, 1606. NORRIS, Alfonso W. Quiroz. Historia de la corrupción en el Perú: es factible su estudio i In:Félix Denegri Luna - homenaje. Lima: Pontificia Universidad Catolica del Perú/Fondo Editorial, 2000, p. 684-690.

OESTREICH, Gerhard. Neostoicism and the Early Modern State. Cambridge: Cambridge University Press, 1982.

Ordenações Afonsinas (1314). Disponível em: http://www. iuslusitaniae. fcsh. unl. pt. Acesso em:13 de jun. 2013.

OROZCO, Sebastián de Covarrubias. Tesoro de la lengua castellana o española. Edición de Felipe C. R. Maldonado revisada por Manuel Camarero. Madrid: Castalia, 1995.

PIETSCHMANN, Horst. Corrupción en las Indias españolas - revisión de un debate en la historiografía sobre Hispanoamérica colonial. In: PIETSCHMANN, Horst, COMÍN, Francisco; PÉREZ, Joseph. Instituciones y corrupción en la historia. Valladolid: Universidad de Valladolid, 1998, p. 31-52.

PIJNING, Ernst. Contrabando, ilegalidade e medidas políticas no Rio de Janeiro no século XVIII. Revista Brasileira de História, v. 21, n. 42, São Paulo, 2001, p. 397-414.

PIJNING, Ernst. Controlling Contraband. Mentality, Economy and Society in Eighteenth-Century Rio de Janeiro. Baltimore: John Hopkins University, 1997.

Primor e honra da vida soldadesca no Estado da Índia. Livro excellente, antigamente composto nas mesmas partes da Índia Oriental, sem nome de autor, \& hora posto em ordem de sair a luz, com hum Elogio sobre elle, pello P. M. Fr. Antonio Freyre. Lisboa: Jorge Rodrigues, 1630.

QUEIRÓS, Silvio Galvão. "Pera Espelho de Todollos Uiuos" - a imagem do Infante D. Henrique na Crônica da Tomada de Ceuta. Dissertação (Mestrado em História), Universidade Federal Fluminense. Niterói, 1997.

ROBLEDO, Antonio Gómez. Fundadores del Derecho Internacional - Vitoria, Gentili, Suárez, Grocio. México: Universidad Autónoma de México, 1989.

RODRÍGUEZ, Manuel Rivero. La edad de oro de los virreyes - el virreinato en la Monarquía Hispánica durante los siglos XVI y XVII. Madrid: Akal, 2011.

SANTA MARIA, Fray Juan de. Republica y policia christiana para reyes y principes y para los que en el gouierno tienen sus vezes, compuesto por Fray Iuan de Santa Maria, religioso descalço, de la Provincia de San Joseph, de la orden de nuestro glorioso padre San Francisco. Barcelona: por Geronimo Margarit, 1619. 
SCHAMA, Simon. O desconforto da riqueza - a cultura holandesa na época de ouro. São Paulo: Companhia das Letras, 1992.

SCHMIDT, Peer. Neoestoicismo y disciplinamiento social en Iberoamérica colonial (siglo XVII). KOHUT, Karl; ROSE, Sonia V. (ed. ). Pensamiento europeo y cultura colonial. Frankfurt, Vervuert Verlagsgesellschaft, Iberoamericana, 1997.

SILVA, Vitor Aguiar e (coord). Dicionário de Luís de Camões. Lisboa, Caminho, 2011.

SILVA, Antônio Moraes. Diccionario da lingua portugueza - recompilado dos vocabulários impressos até agora, e nesta segunda edição novamente emendado e muito acrescentado. Lisboa: Typographia Lacerdina, 1813.

SILVA, José Veríssimo Álvares da. Memória das verdadeiras cauzas porque o luxo tem sido nocivo aos portugueses. In:Memórias econômicas da Academia Real das Sciencias de Lisboa para o adiantamento da agricultura, das artes e da indústria em Portugal e suas conquistas. Lisboa: Officina da Academia Real das Sciencias, 1789,tomo 1.

SILVA, Vitor Aguiar e (coord). Dicionário de Luís de Camões. Lisboa: Caminho, 2011.

SILVEIRA, Francisco Rodrigues. Reformação da milícia e governo do Estado da Índia Oriental. Transcrição, notas e índice Benjamim N. Teensma. Introdução histórica de Luís Felipe Barreto, George Davison Winius, Benjamim N. Teensma. Lisboa:Fundação Oriente, 1996.

SOUSA, Rafaella Caroline Azevedo Ferreira. O rei, os poderes e a literatura - virtudes e pecados na prosa civilizadora de D. Duarte e D. Pedro (Portugal, séculos XIV e XV). Dissertação (Mestrado em História), Universidade Federal Fluminense. Niterói, 2013.

TAWNEY, R. H. La Religión en El Orto del Capitalismo. Madrid: Editorial Revista de Derecho Privado, 1936.

TOLEDO, Cézar de Alencar Arnaut de. "Pedagogia e política nos Tratados de Nobreza Civil e Cristã de Jerônimo Osório da Fonseca." Acta Scientiarum. Human and Social Sciences, v. 28, n. 1, 2006,p. 73-79.

VIEIRA, Antônio. Sermões. Erechim, Edelbra, 1998. Disponível em: http://www. literaturabrasileira. ufsc. br. Acesso em: 10 set. 2013.

VIEIRA, Antônio. Sermões Escolhidos. São Paulo, Edameris, v. 1, 1965. Disponível em: www. dominiopublico. gov. br. Acesso em: 13 mai. 2013.

VIGIER, J. Thesouro apollineo, galenico, chimico, chirurgico, farmacêutico ou compêndio de remédios para ricos \&pobres, por Joam Vigier. Lisboa: Officina Real Deslandesiana, 1714.

VILLALTA, Luiz Carlos. Usos do livro no mundo luso-brasileiro sob as Luzes -reforma,censura e constestações. Belo Horizonte:Fino Traço,2015.

VITORIA, Francisco. La Ley. Madrid: Tecnos, 1994.

WAQUET, Jean-Claude. De la corruption - morale et pouvoir a Florence aux XVIIe. et XVIIIe. siècles. Paris: Fayard, 1984. 